\title{
Sensory involvement in the control of food intake in poultry
}

\section{By Michael J. Gentle, Agricultural and Food Research Council's Poultry Research Centre, Roslin, Midlothian EH25 9PS}

To be able to satisfy the varying nutritional needs of the animal, the selection and ingestion of food items from the environment must be closely monitored both qualitatively and quantitatively. This monitoring is accomplished by a variety of sensory systems of which a simplified outline is presented in Fig 1 .

While it is simpler to consider the stages of food ingestion separately, it must always be stressed that they do not occur in isolation but form a continuum with each phase being closely integrated with the preceding and succeeding ones.

\section{Food recognition}

Birds appear to rely almost exclusively on vision to select food items from the environment but they do have a functional olfactory system so that olfaction cannot be completely excluded. The domestic hen is a nidifugous bird and because the chicks are not fed directly by the parents there is an elaborate system of innate behavioural patterns which protect the animal from ingesting noxious diets. These innate reflexes are subsequently modified by new experiences allowing the birds to

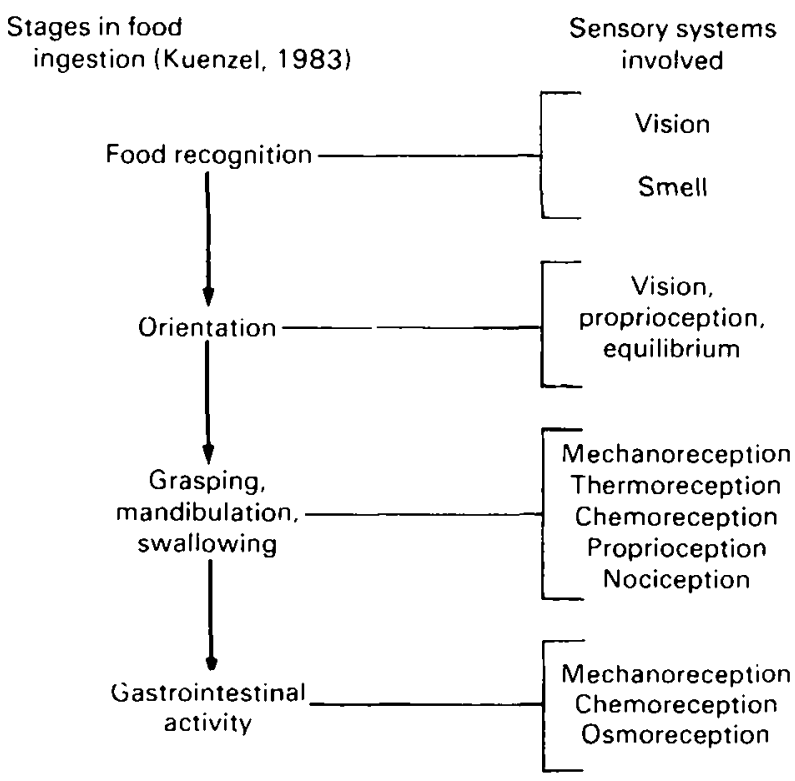

Fig. I. Stages in lood ingestion and sensory systems involved. 
exploit a variety of available food sources. The visual factors can be separated into those which relate directly to the food and those which do not.

\section{Food-related factors}

Newly-hatched chicks appear to have innate preferences for food of certain colours. Hess ( $195^{6}$ ) reported a bimodal colour preference with peaks in the orange and blue region of the spectrum. A preference for green over red was found in domestic-fowl chicks (Capretta, 1969) and in I-d-old turkeys (Cooper, 1971). In contrast, I-d-old chicks reared in the dark have been reported to have an initial preference for red and blue (Salzen et al. 197I) but work by Kovach (197I) suggests that these preferences result from the birds being reared in the dark; they can be eradicated by giving chicks previous experience with achromatic light. Colour preference has also been reported in adult birds (Hurnik et al. 1971).

Innate food preferences are not restricted to colour but also extend to shape (Fantz, 1957; Dawkins, 1968) and size (Schrenk et al. 1963) of the food particles. These innate preferences are easily modified by experience. Taylor et al. (1969) and Capretta (1969) have both shown that the attractiveness of an innately non-preferred colour can be increased by simple exposure to it. The chicken also has a strong bias to use colour in learning situations and on the basis of colour will learn to avoid substances which after ingestion produce illness (Martin et al. 1977; Gillette et al. 1980). Novelty seems to be an important component in these learned illness-induced aversions (Ionescu \& Bures, 1976; Gaston, 1977) and in the discernment of unpalatable substances (Shettleworth, 1972a,b).

The development of food recognition by young, newly-hatched chicks has been extensively studied by Hogan (1971, 1973a,b, 1975, 1977) and by Hogan-Warburg $\&$ Hogan (198I). Young chicks given food and sand learn to ingest primarily food but will still ingest some sand. The increase in food ingestion was probably the result of an association between the visual-tactile-gustatory stimuli from the food and the positive long-term effects of the food ingestion.

\section{Non-food-related factors}

A number of non-food related visual factors are involved in controlling food intake. In the natural environment the mother hen is important in directing attention to food sources (Turner, 1964; Hogan, I 973a; Savory et al. 1978). Young chicks eat more food in the presence of an active companion than in isolation and this has been called social facilitation (Tolman, 1964, 1965, 1968; Tolman \& Wilson, 1965). It has been argued that social facilitation is responsible for the increase in growth rate of group-reared chicks (Schrenck et al. 1963) but Savory (1975) showed that these differences in growth rate were due to food conversion efficiency. Social facilitation seems to play an important role in the initiation of pecking (Strobel \& Macdonald, I974). These social factors in chicks have the effect of synchronizing the feeding of whole groups and a similar tendency is seen in adult birds (Hughes, 1971). 


\section{Olfaction}

The sense of smell in birds has received very little attention but there is experimental evidence to show that kiwis, petrels and shearwaters can locate their food by smell (Wenzel, 1968; Grubb, 1972). The chicken has a functional olfactory system (Tucker, 1965; Tolhurst $\&$ Vince, 1976) and by using operant-conditioning techniques, olfactory thresholds to various hydrocarbons have been determined (Stattelman et al. 1975). Some recent work (Jones \& Gentle, 1985) suggests that domestic chicks can regulate their behaviour in response to olfactory factors. While there is no direct evidence for the chicken using olfaction in feeding, studies involving olfactory-bulb ablation in relation to food intake and obesity (Robinzon et al. 1977) suggest that it cannot be excluded.

\section{Orientation}

It is self-evident that the sensory systems responsible for maintaining the position of the head relative to the body are vital for feeding. A number of studies have shown that certain brain lesions in areas not directly involved in primary sensation will greatly interfere with the animals' ability to orientate correctly to food. Salzen \& Parker (1975) proposed that the hyperstriatum provides a fine degree of orientation and produces arousal to fine stimulus differences: because it receives a wide variety of sensory inputs it can distinguish the detailed features of the stimulus object or situation. Following hyperstriated ablation, several birds were observed to show long periods of aphagia (Gentle et al. 1978). Deficits in the orientation phase of feeding behaviour resulted from bilateral lesions in the ansa lenticularis (Kuenzel, 1982). After bilateral lesion the birds approached grains of food but when they attempted to consume them they either pecked the air or struck a matted surface to the left or right of the food particles.

\section{Grasping, mandibulation, swallowing}

The amount and type of food eaten during a meal results from a combination of various internal and external signals, particularly oropharyngeal stimulation by the sensory characteristics of the food. To be able to grasp, mandibulate and swallow food, feedback from receptors in the oral cavity, pharynx and upper oesophagus is required. The cranial nerves which relay this sensory information to the brain are the trigeminal, facial, glossopharyngeal, vagus and hypoglossal nerves. The alteration of sensory feedback from the mouth results in a marked reduction in food intake. Section of the trigeminal nerves in the pigeon (Zeigler, 1973, 1975) or lesions in the trigeminal system in the brain (Zeigler \& Karten, 1973a,b) resulted in aphagia, which may last for several days or months, followed by a period of anorexia during which body-weight is regulated at less than that of free feeding control animals. Since neither drinking nor preening behaviour was disrupted, it was postulated that deafferentation affects neural processes specific to the control of responsiveness to food (i.e. hunger) rather than reflecting a more generalized disruption of the sensorimotor mechanisms involved in pecking behaviour. A 
detailed account of trigeminal sensorimotor circuit for pecking, grasping and feeding in the pigeon has been recently presented by Wild et al. (1984). Macleod (1978) has, however, proposed that trigeminal nerve section alters the bird's perception of food to such an extent that it was no longer regarded as food. Aphagia as a result of sensory deafferentation is thus analogous to food neophobia and, in a series of experiments giving birds novel diets, he was able to show that they exhibited a marked aphagia and one animal would not accept the novel diet at all.

Aphagia followed by a period of anorexia is also seen following section of the lingual and laryngo-lingual branches of the glossopharyngeal nerves (Gentle, 1971, 1978). It is interesting to note that following lingual nerve section the birds also showed a pronounced neophobia.

The receptors present in the mouth consist of mechanoreceptors, thermoreceptors, chemoreceptors and nociceptors. In considering oral receptors it must be stressed that they are not acting in isolation; for example, gustatory stimuli normally have concomitant tactile and thermal components.

\section{Mechanoreceptors}

Physiologically there are two types of mechanoreceptors present in the oral cavity: those which adapt rapidly, and those which adapt slowly to a mechanical stimulus.

The rapidly-adapting mechanoreceptors are of two types: those which give a single response to a mechanical displacement and those which give a short group or burst of responses to the same displacement. Herbst's corpuscles are thought to be responsible for the single-response type and Grandry corpuscles for the short-burst type (Malinovsky, 1967; Dorward, 1970; Gregory, 1973; Gottschaldt, 1974; Leitner \& Roumy, 1974a; Saxod, 1978; Berkhoudt, 1980). Both of these rapidly adapting mechanoreceptors respond only to the onset of the stimulus and do not respond to a static displacement. The Herbst corpuscles, unlike the Grandry corpuscles, respond to a vibrating mechanical stimulus in the response range of $40-1500 \mathrm{~Hz}$.

The slowly-adapting mechanoreceptors give a prolonged response to mechanical displacement and are common in the trigeminal system of geese (Gottschaldt, 1974) and pigeons (Necker, 1973). Slowly-adapting mechanoreceptors have been identified in the oral cavity of the chicken. We have recently recorded the electrical activity from single cells in the geniculate ganglion and have identified slowly-adapting mechanoreceptors from various branches of the facial nerve. It is thought that these slowly-adapting mechanoreceptors may be responses from free nerve endings.

\section{Thermoreceptors}

Cold receptors have been identified in the mouth and they respond to cooling of the surface of the beak and oral epithelium (Kitchell et al. 1959; Gregory, 1973; Necker, 1973; Leitner \& Roumy, 1974b). Warm receptors responding to an 
increase in temperature, have been found in the pigeon (Necker, 1972, 1973; Necker \& Reiner, 1980) but not in the chicken (Kitchell et al. 1959).

\section{Chemoreceptors}

As in mammals, the chemoreceptor cells of avian species are clustered into taste buds, there being an average 360 taste buds in the oral cavity of the chicken (Saito, 1966); this is about half the number found in the hamster (Miller \& Smith, $198_{4}$ ) and $29 \%$ of those found in the rat (Miller \& Spangler, 1982). The distribution of the taste buds in the chicken is of interest as $54 \%$ are in the palate, $42 \%$ in the floor of the oral cavity and only $4 \%$ in the tongue. In the hamster (Miller \& Smith, $1984) 73 \%$ are in the tongue and only $13.8 \%$ in the palate. In the Mallard the taste buds are situated in the areas of the mouth where there is prolonged contact with food and would thus enable better gustatory discrimination (Berkhoudt, I977); a similar argument may hold for the chicken.

It was originally thought that taste information was relayed to the brain entirely along branches of the glossopharyngeal nerve (Kitchell et al. 1959) but recent work has shown that the chorda tympani branch of the facial nerve has an important role in taste perception (Gentle, 1983). The chorda tympani relays taste information from those taste buds in the anterior mandibular area. Some recent recordings we have taken from the geniculate ganglion show that many of the taste buds in the palate also send information to the brain along other branches of the facial nerve.

Chickens have an acute sense of taste (Gentle, 1975) and changes in taste preferences occur readily following experimental manipulation. When fed on a diet adequate in energy, the chicken did not exhibit any marked preference for a sucrose solution ( $100 \mathrm{~g} / \mathrm{l})$ but when fed on a diet low in energy they showed a marked preference for the sucrose (Kare \& Maller, 1967). Gustatory cues are also used to select calcium carbonate-supplemented diets when $\mathrm{Ca}$ is lacking (Hughes \& Wood-Gush, 197I). In these experiments the birds' gustatory behaviour is altered as a result of the consequences of ingesting the food and this is very clearly demonstrated in condition-aversion studies. Birds rapidly form conditioned aversion to weakly-flavoured solutions (Lett, 1980; Westbrook et al. 1980; Gillette et al. 1983) but not to strongly-flavoured foods (Gillette et al. 1980; Gillette et al. $1983)$. Even after short periods of water deprivation, the chicken will accept solutions which would have been unacceptable previously (Gentle, 1976) and it was suggested that this increase in acceptability may be due to changes in taste sensitivity. Changes in hydration will also affect the birds' response to water: after deprivation, water is positively rewarding but after loading the crop with water further water in the mouth is stressful (Gentle, 1974). Many of the conditions which alter the animals' behavioural responses to gustatory stimuli also evoke visceral afferent activity. Both gustatory (Dubbeldam et al. 1976, 1979; Dubbeldam, 1984; Gentle 1979a) and visceral afferents (Katz \& Karten, 1983) project on to the nucleus of the solitary tract within the medulla. How visceral afferent information affects behaviour is not known but one possibility is that it interacts with oral or gustatory activity (Norgren, 1983). This interaction might 
take place in the nucleus of the solitary tract or caudal brain stem and in the rat, neurons responsive to chorda tympani as well as cervical vagus nerve stimulation were identified electrophysiologically in the caudal brain stem (Bereiter et al. I98I).

Oral behaviour in response to gustatory stimulation usually consists of mandibulatory movements of the beak coupled with movements of the tongue and swallowing. Head-shaking and beak-wiping where the birds rapidly stroke alternate sides of the beak on the sides or floor of the cage are also seen. The behavioural sequence is not rigid. Although beak and tongue movements occur over several minutes, beak-wiping does not necessarily follow a period of headshaking and the ratio of the different behaviour components to each other does not remain the same (Gentle \& Harkin, 1979). Changes in oral behaviour can occur following both vitamin A (Gentle \& Dewar, I98I) and zinc deficiencies (Gentle et al. $198 \mathrm{I}$ ). Of these behaviour patterns, beak-wiping was abolished by removal of the anterior telencephalon and head-shaking by the removal of both the telencephalon and diencephalon. Beak and tongue movements are still present after this surgery and are therefore organized in, or caudal to, the midbrain (Gentle, 198I).

\section{Nociceptors}

The presence of specific nociceptors which respond to various thermal or mechanical stimulation, or both, have been identified in the chicken beak (Breward, 1984). The thermal response threshold was found to be in the range $41-56^{\circ}$. These results explain the observations that chickens drink very little, if any, water if it is at $45^{\circ}$ (Gates \& Kare, 196I; Gentle, 1979b). While it is unlikely that birds would normally encounter water at $45^{\circ}$ they are likely to peck at solid items at that temperature and damage the oral epithelium and stimulate nociceptors.

\section{Gastrointestinal activity}

We know least of all about the receptors in the gastrointestinal tract. Work by Richardson (1970) showed that the artificial inflation of the crop by a permanently-implanted balloon reduced the amount of food a bird ate. Subsequently, Hodgkiss (198I) has demonstrated the presence of two types of distension-sensitive receptors in the crop of the chicken, slowly-adapting receptors and rapidly-adapting receptors, the former being encountered about four times more frequently than the latter. The slowly-adapting receptors are capable of signalling distension of the crop for prolonged periods of time although small local changes in tension may modulate the firing rate. The only other piece of direct evidence for gastrointestinal receptors comes from the work of Duke et al. (1977) who reported mechanoreceptors present in the gizzard. A number of studies (Gentle \& Richardson, 1972; Richardson \& Gentle, 1972; Shurlock \& Forbes, I $981 a$; Gentle et al. 1982) have suggested the presence of thermoreceptors, chemoreceptors or osmoreceptors in the crop and duodenum. The work of Shurlock \& Forbes ( $198 \mathrm{r} a$ ) is of interest as it suggests that in relation to food 
intake there is a major osmotic control in the duodenum which may affect a secondary control system in the upper gastrointestinal tract. Further work by the same authors (Shurlock \& Forbes, I $98 \mathrm{I} b$ ) has demonstrated a glucose-dependent mechanism for the control of food intake which exists in the hepatic area of the chicken.

\section{Conclusions}

In the present paper I have examined the role of some of the sensory systems involved in controlling food intake by considering their role in monitoring food items qualitatively and quantitatively. Our knowledge is, however, only fragmentary and we have little information on the receptors present in the alimentary canal or those receptors which measure circulating nutrients. For food intake to be controlled effectively the activity of this vast array of receptors, both internal and external, are integrated within the central nervous system where the fine adjustments can be made.

\section{REFERENCES}

Bereiter, D. A., Berthoud, H. R. \& Jeanrenaud, B. (1981). Brain Research Bulletin 7, 261-266.

Berkhoudt, H. (1977). Netherlands Journal of Zoology 27, 3 10-33 I.

Berkhoudt, H. (1980). Netherlands Journal of Zoology 30, I-34.

Breward, J. (1984). Fournal of Physiology 346, 56P.

Capretta, P. J. (1 969). Animal Behaviour 17, 229-231.

Cooper, J. B. (1971). Poultry Science 50, 1892-1893.

Dawkins, R. (1968). Zeitschrift für Tierpsychologie 25, 170-186.

Dorward, P. K. (1970). Comparative Biochemistry and Physiology 35, 729-735.

Dubbeldam, J. L. (1984). Brain Behaviour and Evolution 24, 47-57.

Dubbeldam, J. L., Brus, E. R., Menken, S. B. J. \& Zeilstra, S. (1979). Fournal of Comparative Neurology $183,149-168$.

Dubbeldam J. L., Karten, H. J. \& Menken, S. B. J. (1976). Journal of Comparative Neurology I 70, 4I $5-420$.

Duke, G. E., Kuhlman, W. D. \& Fedde, M. R. (1 977). Poultry Science 56, 297-299.

Fantz, R. L. (1 957). Journal of Comparative and Physiological Psychology 50, 422-430.

Gaston, K. E. (1977). Behavioural Biology 20, 44 I-453.

Gates, J. D. \& Kare, M. R. (I96I). Poultry Science 40, 1407.

Gentle, M. J. (1971). British Poultry Science 12, 77-86.

Gentle, M. J. (1974). Physiology and Behaviour 13, 15-19.

Gentle, M. J. (1975). In Neural and Endocrine Aspects of Behaviour in Birds, pp. 305-318 [P. Wright, P. G. Caryl and D. M. Vowles, editors]. Amsterdam: Elsevier.

Gentle, M. J. (1976). Chemical Senses and Flavour 2, I $21-128$.

Gentle, M. J. (1978). Chemical Senses and Flavour 3, 325-329.

Gentle, M. J. (1979a). Fournal of Comparative Physiology 130, 259-264.

Gentle, M. J. (1979b). British Poultry Science 20, 533-539.

Gentle, M. J. (1981). Behaviour Processes 6, 109-120.

Gentle, M. J. (1983). Experientia 39, 1002-1003.

Gentle, M. J. \& Dewar, W. A. (1981). British Poultry Science 22, 275-279.

Gentle, M. J., Dewar, W. A. \& Wright, P. A. L. (198I). British Poultry Science 22, 265-273.

Gentle, M. J., Dewar, W. A., Wright, P. A. L. \& Dick, K. M. (1982). Appetite 3, 53-60.

Gentle, M. J. \& Harkin, C. (1979). Chemical Senses and Flavour 4, 183-190.

Gentle, M. J. \& Richardson, A. (1972). British Poultry Science 13, 163-170.

Gentle, M. J., Wood-Gush, D. G. M. \& Gordon, J. (1978). Behavioural Processes 3, I $37-148$.

Gillette, K., Martin, G. M. \& Bellingham, W. P. (I980). Fournal of Experimental Psychology: Animal Behaviour Processes 6, 99-I I I. 
Gillette, K., Thomas, D. K. \& Bellingham, W. P. (1983). Chemical Senses 8, $41-57$.

Gottschaldt, K. M. (1974). Journal of Comparative Physiology 95, 29-47.

Gregory, J. E. (1973). Fournal of Physiology 229, $151-164$.

Grubb, T. C. (1972). Nature 237, 404-405.

Hess, E. H. (1956). Psychological Reports 2, 477-483.

Hodgkiss, J. P. (I $98 \mathrm{r}$ ). Comparative Biochemistry and Physiology $70 \mathrm{~A}, 73-78$.

Hogan, J. A. (1971). Behaviour 39, I 28-201.

Hogan, J. A. (1973a). Fournal of Comparative and Physiological Psychology 83, 355-366.

Hogan, J. A. (1973b). Journal of Comparative and Physiological Psychology 83, 367-373.

Hogan, J. A. (1975). Journal of Comparative and Physiological Psychology 89, 95-104.

Hogan, J. A. (1977). Fournal of Comparative and Physiological Psychology 91, 839-850.

Hogan-Warburg, A. J. \& Hogan, J. A. (198I). Animal Behaviour 29, 143-154.

Hughes, B. O. (1971). British Poultry Science 12, 359-366.

Hughes, B. O. \& Wood-Gush, D. G. M. (1971). Animal Behaviour 19, 490-499.

Hurnik, J. F., Jerome, F. M., Reinhart, B. S. \& Summers, J. D. (1971). Poultry Science 50, $944-949$.

Ionescu, E. \& Bures, J. (1976). Behavioural Processes I, 233-24I.

Jones, R. B. \& Gentle, M. J. (1985). Physiology and Behaviour 34 (In the Press).

Kare, M. R. \& Maller, O. (1967). Fournal of Nutrition 92, 191-196.

Katz, D. M. \& Karten, H. J. (1983). Fournal of Comparative Neurology 218, 42-73.

Kitchell, R. L., Strom, L. \& Zotterman, Y. (1959). Acta Physiologica Scandanavica 46, 133-1 5 1.

Kovach, J. K. (1971). Fournal of Comparative and Physiological Psychology 75, 386-398.

Kuenzel, W. J. (1982). Society for Neuroscience 8, 599.

Kuenzel, W. J. (1983). Bird Behaviour 5, 2-1 5 .

Leitner, L. M. \& Roumy, M. (1974a). Pflugers Archiv für die gesamte Physiologie des Menschen und der Tiere 346, $14{ }^{1-1} 5^{\circ}$.

Leitner, L. M. \& Roumy, M. (1974b). Pflugers Archiv für die gesamte Physiologie des Menschen und der Tiere 346, $151^{-1} 55$.

Lett, B. T. (1980). Animal Learning and Behaviour 8, 193-198.

Macleod, H. A. (1978). Control of feeding patterns in the Banbury dove (Streptopelia risoria). $\mathrm{PhD}$ Thesis, University of Edinburgh.

Malinovsky, L. (1967). Zeitschrift für mikroskopisch-anatomische Forschung 77, 279-303.

Martin, G. M., Bellingham, W. P. \& Storlien, L. H. (1977). Physiology and Behaviour 18, 415-420.

Miller, I. J. Jr \& Smith, D. V. (1984). Physiology and Behaviour 32, 275-285.

Miller, I. J. Jr \& Spangler, K. M. (1982). Chemical Senses 7, 99-108.

Necker, R. (1 972). Journal of Comparative Physiology 78, 307-314.

Necker, R. (1 973). Fournal of Comparative Physiology 87, 379-391.

Necker, R. \& Reiner, B. (1 980). Fournal of Comparative Physiology 135, $201-208$.

Norgren, R. (1983). Fournal of the Autonomic Nervous System 9, 67-77.

Richardson, A. J. (1 970). Animal Behaviour 18, 633-639.

Richardson, A. J. \& Gentle, M. J. (1972). British Poultry Science 13, 171-173.

Robinzon, B., Snapir, N. \& Perek, M. (1 977). Brain Research Bulletin 2, 465-474.

Saito, I. (1966). Bulletin of the Faculty of Agriculture, Miyasahi University 13, 95-102.

Salzen, E. A., Lily, R. E. \& McKeown, J. R. (1971). Animal Behaviour 19, 542-547.

Salzen, E. A. \& Parker, D. M. (1975). In Neural and Endocrine Aspects of Behaviour in Birds, pp. 205-242 [P. Wright, P. G. Caryl and D. M. Vowles, editors]. Amsterdam: Elsevier.

Savory, C. J. (1975). British Poultry Science 16, 343-350.

Savory, C. J., Wood-Gush, D. G. M. \& Duncan, I. J. H. (1978). Applied Animal Ethology 4, $13-27$.

Saxod, R. (1978). In Handbook of Sensory Physiology, vol. 9, pp. 338-4I 7 [M. Jacobson, editor]. Berlin: Springer Verlag.

Schrenk, P. K., Sterritt, G. M., Smith, M. P. \& Stilson, D. W. (1963). Animal Behaviour II, 306-309.

Shettleworth, S. J. (1972a). Animal Behaviour 20, 29-35.

Shettleworth, S. J. (1972b). Fournal of Comparative and Physiological Psychology 80, 175-198.

Shurlock, T. G. H. \& Forbes, J. M. (1981a). British Poultry Science 22, 323-331.

Shurlock, T. G. H. \& Forbes, J. M. (1981b). British Poultry Science 22, 333-346. 
Stattelman, A. J., Talbot, R. B. \& Coulter, D. B. (1975). Comparative Biochemistry and Physiology 50A, 807-809.

Strobel, M. G. \& Macdonald, G. E. (1974). Fournal of Comparative and Physiological Psychology 86, 493-502.

Taylor, A., Sluckin, W. \& Hewitt, R. (1969). Animal Behaviour 1 7, 3-8.

Tolhurst, B. E. \& Vince, M. (1976). Animal Behaviour 24, 772-779.

Tolman, C. W. (1964). Animal Behaviour 12, 245-251.

Tolman, C. W. (1965). Animal Behaviour 13, 493-496.

Tolman, C. W. (1968). Behaviour 30, 275-286.

Tolman, C. W. \& Wilson, G. F. (1965). Animal Behaviour 13, $134-142$.

Tucker, D. (1965). Nature 207, 34-36.

Turner, E. R. A. (1964). Behaviour 24, $1-46$.

Wenzel, B. M. (1 968). Nature 220, I I 33 - I I 34 .

Westbrook, R. F., Clarke, J. C. \& Provost, S. (1980). Behavioural and Neural Biology 28, 398-407.

Wild, J. M., Arends, J. J. A. \& Zeigler, H. P. (1984). Brain Research 300, 146-151.

Zeigler, H. P. (1973). Science 182, I1 $55^{-1} 157$.

Zeigler, H. P. (1975). Journal of Comparative and Physiological Psychology 89, 827-844.

Zeigler, H. P. \& Karten, H. J. (1973a). Fournal of Comparative Neurology 152, 59-82.

Zeigler, H. P. \& Karten, H. J. (1 973 b). Fournal of Comparative Neurology 152, 83-102. 